\title{
TECHNOLOGICAL INNOVATION IN THE ASPECT OF SAFETY IN THE PROCESS OF HEAT SUPPLY
}

doi: $\quad 10.2478 /$ czoto-2019-0053

Date of submission of the article to the Editor: 30/11/2018

Date of acceptance of the article by the Editor: 12/01/2019

\author{
Aleksandra Wrzalik ${ }^{1}$ - orcid id: 0000-0002-3859-4954 \\ Matevž Obrecht ${ }^{2}$ - orcid id: 0000-0001-8301-7382 \\ ${ }^{1}$ Czestochowa University of Technology - Poland, aleksandra.rak@wz.pcz.pl \\ ${ }^{2}$ University of Maribor - Slovenija
}

\begin{abstract}
In recent years heating in Poland has been transformed as a result of the priorities of the country's energy policy implemented within the European Union. The increase in energy security, the development of renewable energy sources and the fulfilment of legal and environmental requirements are very important. Exploitation of district heating systems should ensure reliable and safe heat supplies for industrial and municipal customers with high energy efficiency and reduction of environmental impact. The article discusses the conditions and directions of centralized heating systems development as well as technical and economic issues, which are important for the security of heat supply. The Author describes selected technological innovations used in the technical infrastructure for heat transfer and modern IT systems which are improving the management of heating systems. The article includes the results of simulation research with use of IT tools showing the impact of selected innovations on the improvement of network operation conditions. Directions of modernization of heating systems in the aspect of increasing energy efficiency and security of heat supply have also been indicted here.
\end{abstract}

Keywords: technological innovations, security of heat supply, IT systems

\section{INTRODUCTION}

The supply of heat to customers in urban agglomerations in Poland takes place from centralized heating systems, which consist of the following elements (Rak, 2017):

- source that produces heat in the necessary amount with specified parameters,

- heating network supplying the heating medium to recipients,

- heating nodes transforming the parameters of the heating medium,

- indoor installations in heated buildings.

The energy policy of the country implemented under European Union regulations has a significant influence on the conditions of functioning and development of heating systems. The basic directions of this policy relating to heat engineering in Poland are:

- improving energy efficiency and increasing the efficiency of systems,

- sustainable development and increased use of renewable energy sources, 
- energy security and development of competitive fuel and energy markets,

- reducing the negative influence on the environment.

The increase of energy efficiency is a priority binding for the implementation of other objectives of the Polish energy policy. For the development of district heating, Directive 2012/27 / EU on energy efficiency, in which the "effective district heating and cooling system" was defined, is significant. This implies supporting the adaptation of existing infrastructure (heat sources and heating networks) for the use and development of high-efficiency cogeneration, including waste heat and renewable energy (Turski and Sekret, 2015). Improvement of energy safety and efficiency as well as ecological indicators in the area of heat supply require comprehensive modernization and implementation of innovative technological solutions. This applies to all segments forming the local heat market (Jachura and Sekret, 2015; Wojdyga and Chorzelski, 2017):

- heat production - development of cogeneration and trigeneration systems, change of energy production technology, use of fuels with lower environmental load,

- heat transfer - construction of intelligent heating networks (smart grid), exchange of pre-insulated pipes networks, automation systems, monitoring and management of network operation, hydraulic regulation, lowering the temperature of the heating medium, heat storage,

- building and installation systems at the recipients - implementation of the lowenergy construction standard, thermo-modernization of buildings, modernization of heating nodes, increasing the use of renewable energy sources.

The future of heat supply systems is integrated heat networks within general sustainable energy systems using renewable energy sources - 4G-hybrid heating networks with reduced performance (Rezaie and Rosen, 2012; Lund et al., 2014).

\section{SECURITY ISSUES OF HEAT SUPPLY}

Ensuring the country's energy security is one of the main priorities of the current energy policy. The main objective is to cover the current and long-term demand of consumers for fuels and energy, while minimizing the negative impact on the environment. The energy security of district heating systems depends mainly on the size of production capacity, the technical condition of the transmission infrastructure and the degree of diversification of the fuel base. Potential external and internal threats affecting, to varying degrees, the security of heat supply to recipients are given in Table 1.

Table 1.

Internal and external factors affecting the energy security of heating systems

\begin{tabular}{|c|c|}
\hline Internal threats & External threats \\
\hline 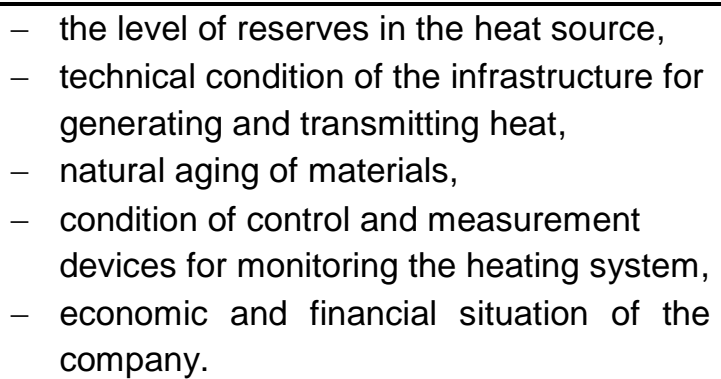 & $\begin{array}{l}\text { - climatic hazards (temperature, icing, } \\
\text { flooding or wind), } \\
\text { - } \text { interruptions in the power supply, } \\
\text { - } \text { poor fuel quality and disruptions in its } \\
\text { delivery, } \\
\text { - } \text { failure of the water supply network, } \\
-\quad \text { untimely delivery of equipment and } \\
\text { materials. }\end{array}$ \\
\hline
\end{tabular}

Source: own elaboration 


\section{TECHNOLOGICAL INNOVATIONS IN THE INFRASTRUCTURE OF HEAT TRANSFER}

Introduction of technological innovations in heating enterprises results from market conditions (reduction of power, development of renewable energy and prosumer energy) and the need to ensure reliability of the heating system operation and heat supply efficiency (Turski and Sekret, 2015). Innovative solutions include modernization of the transmission network infrastructure and installation of control and measurement devices for monitoring and management of the heating network. Energy efficiency and reliability of the district heating network can be improved through (Wojdyga and Chorzelski, 2017):

- reduction of heat transmission losses from heating pipelines,

- conducting hydraulic analyses for pipeline systems,

- operation of a few heat sources for a joint network in the heating system,

- building systems of heat and power cogeneration based on the demand for usable hot water,

- using heat reservoirs to balance fluctuations in heat demand.

The effect of reducing heat transmission losses in the district heating network as a result of thermo-modernization of overhead networks for the distribution of temperatures in a typical heating season is shown in Figure 1.

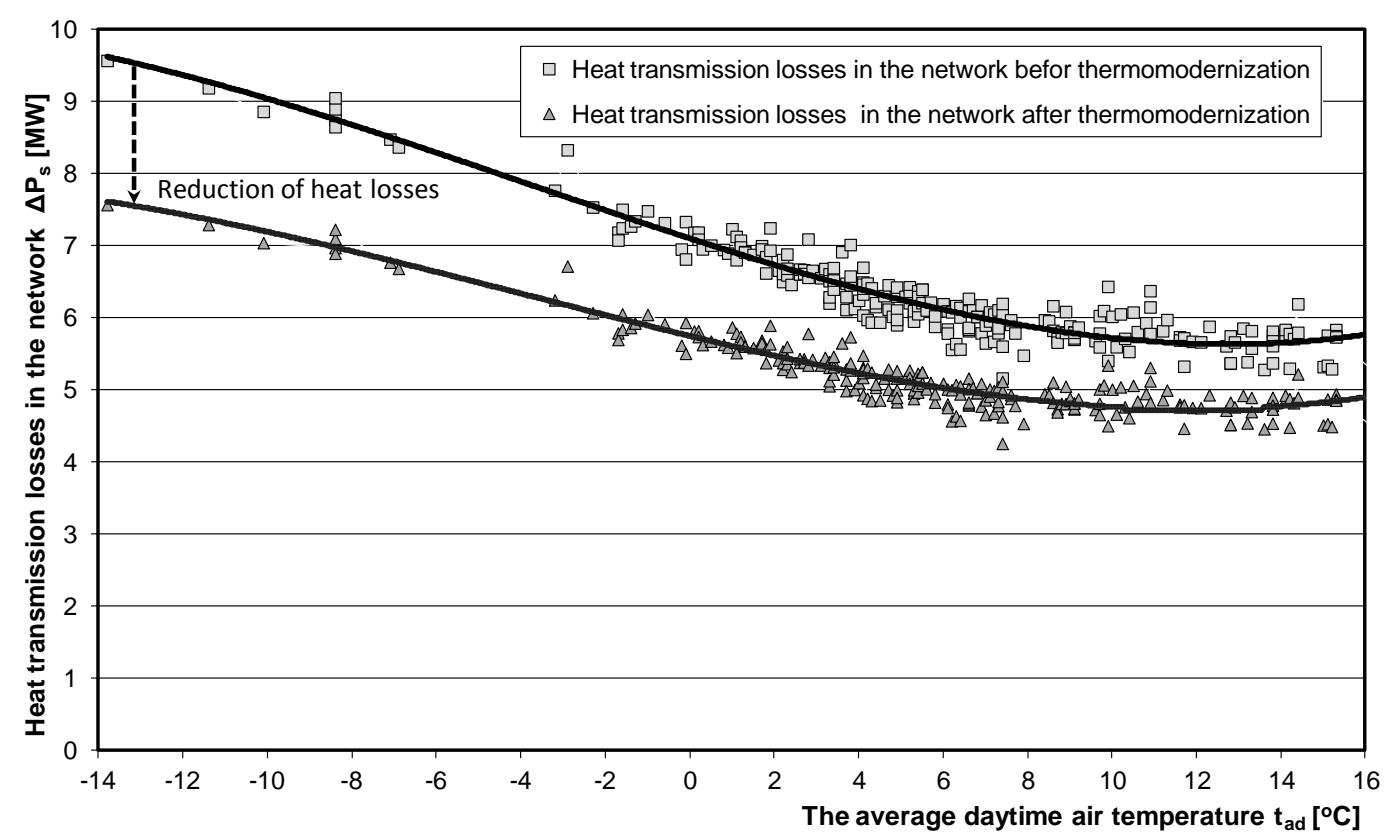

Fig. 1. Comparison of heat transmission losses $\Delta P_{s}$ in the district heating network for the current state and the state after the thermo-modernization of overhead networks (simulation)

Source: own elaboration

Significant reduction of losses in the heating network is possible as a result of lowering the network water temperature for CHP blocks generating heat in combination with electricity. The advantages of low temperature district heating include (Imran et al., 2017):

- reduction of heat losses in the network,

- reducing pipeline the thermal stress,

- possibility of connecting many renewable heat sources (recipients), 
- increased utilization of thermal storage units,

- improving the power to heat ratio in the CHP system.

The use of an auxiliary heat storage pipe in a low-temperature district heating system enables heat exchange between the heat supplier and the prosumers, who operating their own distributed energy generation unit. This allows to significantly mitigate the inefficiency arising from mismatching of heat demand and supply on the consumer's side (Im and Liu, 2018). The efficient exploitation of heating systems is provided by control and measurement systems for monitoring and controlling the operation of the network. These are the following solutions (Komosa and Kiedrowski, 2013):

- telemetry used within the technology of pre-insulated transmission networks,

- common automation of the operation of heating nodes,

- control systems and heat source work programs.

\section{APPLICATION OF IT TOOLS TO MANAGE THE HEAT DELIVERY PROCESS}

In the management of heat generation and supply systems, technological innovations rely on the use of IT tools and teletransmission systems (Rak A., 2016). The use of distributed control systems and SCADA-type packages (InTouch, WinCC, iFIX, etc.) makes it possible to visualize the operation of the heating system and remote control of the operation of individual devices. Visualization systems facilitate ongoing operation and improve the economic efficiency of network management (Rak A., 2018).

The implementation of software packages dedicated to the heating industry ensures ongoing control of the operation status of heating systems and gives the opportunity to analyze static and dynamic states occurring in real conditions. Currently, a number of advanced programs for modeling and optimization of heating networks are available on the market (Olsthoorn et al., 2016). One of them is the TERMIS program (Figure 2) tested in national heating networks.

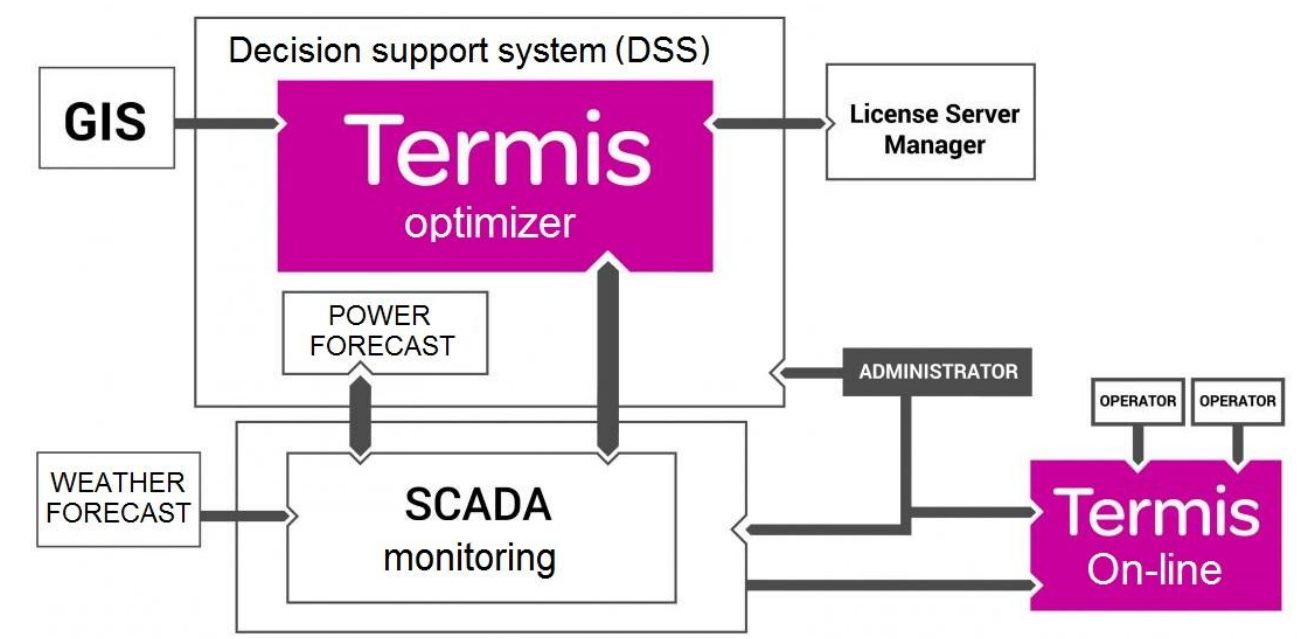

Fig. 2. Heating software TERMIS - decision support system (DSS)

Source: https://it.kelvin.pl/termis-system-wsparcia-decyzji-swd [access 17.11.2018]

In order to reduce costs and improve the energy efficiency of the heat supply process, the optimization of network operation parameters is increasingly used. This involves predicting the future demand for heat and the temperature of the return water on the basis of the forecast outside temperature and the history of process data. On this basis, the supply water temperature and the flow rate are adjusted (Laakkonen et al., 
2017). The optimization of the supply temperature in the heating system using the TERMIS program is shown in Figure 3.
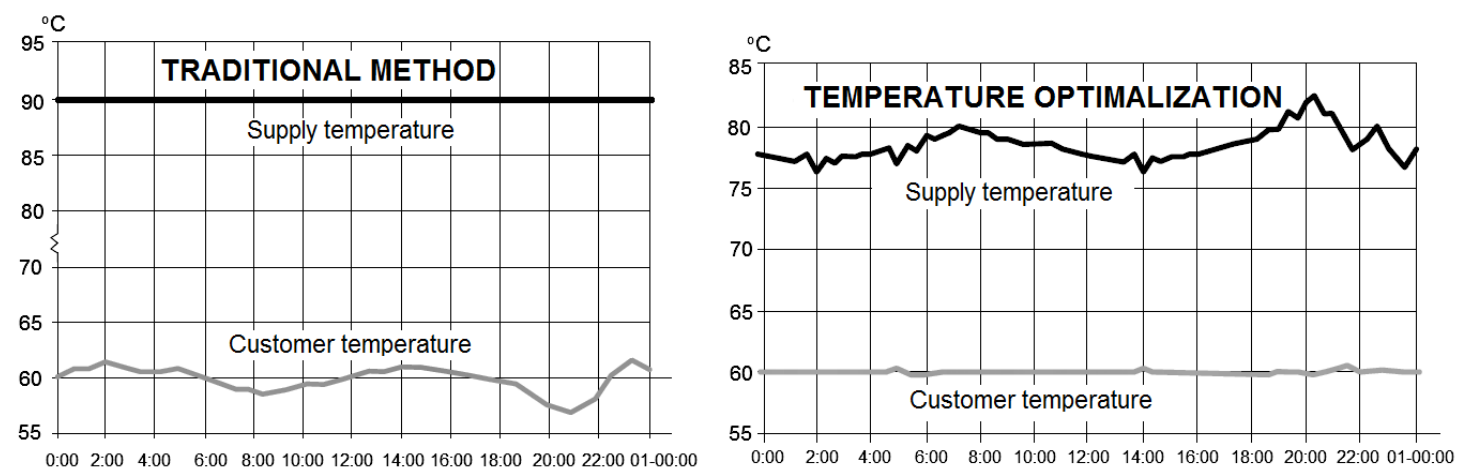

Fig. 3. Optimization of the flow temperature in the heating system using the TERMIS program Source: developed according to TSB-TemperatureOptimization-eng.pdf https://www.schneider-electric.com.ng/en/download/document/TSB-TemperatureOptimization-eng/

The introduction of market models for heat supply, based on technical parameters and a cost account, enables the improvement of the operational efficiency of the heating system and optimization of investment processes both for a single enterprise and in the whole sector (Sarma and Bazbauers, 2016; Sipilä et al., 2016). A comprehensive approach to the innovation management process in heating must include not only technological aspects but also organizational solutions and decisionmaking processes (White and Bruton, 2011, Tidd and Bessant, 2018).

\section{CONCLUSION}

In order to ensure energy security and maintain the continuity of heat supplies to customers, domestic heating companies must develop and modernize the infrastructure of heating systems. Current trends in the development of urban agglomerations and low-energy construction in Poland create new challenges and perspectives. They concern the introduction of modern technical solutions and technological innovations. In the dynamically changing environment, coordinating activities undertaken to increase production efficiency and optimize the heat delivery process and provide new services (cold distribution) is not possible without comprehensive business management. The implementation of smart grids and their operation require the use of specialized IT tools. They enable analysis of the demand for individual energy carriers and optimal control of production systems (central and distributed) and energy distribution. Innovative projects through the synergy of the latest technology, IT and telecommunications achievements improve the efficiency and reliability of the network heat generation and distribution processes. The use of specialized software makes it possible to control and optimize the operation of the heating system taking into account changing climatic conditions, which reduces heat loss and increases the energy efficiency of the system. 


\section{REFERENCES}

Directive 2012/27/EU of the European Parliament and of the Council of 25 October 2012 on energy efficiency, ... (OJ L 315 14.11.2012).

https://it.kelvin.pl/termis-system-wsparcia-decyzji-swd [access 17.11.2018].

Im, Y.H., Liu, J., 2018. Feasibility study on the low temperature district heating and cooling system with bi-lateral heat trades model. Energy, 153, 988-999; DOI: 10.1016/j.energy.2018.04.094

Imran, M., Usman, M., Im, Y.H., Park, B.S., 2017. The feasibility analysis for the concept of low temperature district heating network with cascade utilization of heat between networks. Energy Procedia, 116, 4-12.

DOI: 10.1016/j.egypro.2017.05.050

Jachura, A., Sekret, R., 2015. Poprawa wykorzystania mocy cieplnej miejskiego systemu ciepłowniczego poprzez uwzględnienie krótkookresowego zapotrzebowa-nia na ciepło. Rynek Energii, 5, 24-30.

Komosa, M.K., Kiedrowski, W.I., 2013. Inteligentne systemy informatyczne dla koncesjonowanego sektora ciepłowniczego, Ciepłownictwo, Ogrzewnictwo, Wentylacja 44/2, 47-52.

Laakkonen, L., Korpela, T., Kaivosoja, J., Vilkko, M., Majanne, Y., Nurmoranta, M., 2017. Predictive Supply Temperature Optimization of District Heating Networks Using Delay Distributions. Energy Procedia, 116, 297-309.

DOI: 10.1016/j.egypro.2017.05.076

Lund, H., Werner, S., Wiltshire, R., Svendsen, S., Thorsen, J.E., Hvelplund, F., Mathiesen, B.V., 2014. 4th Generation District Heating (4GDH): Integrating smart thermal grids into future sustainable energy systems. Energy, 68, 1-11, DOI: 10.1016/j.energy.2014.02.089

Olsthoorn, D., Haghighat, F., Mirzaei, P.A., 2016. Integration of storage and renewable energy into district heating systems: $A$ review of modelling and optimization. Solar Energy, 136, 49-64. DOI: 10.1016/j.solener.2016.06.054.

Rak, A., 2016. Narzędzia informatyczne do zarządzania i optymalizacji pracy systemu ciepłowniczego. Zeszyty Naukowe UE w Katowicach, 308, 115-127.

Rak, A., 2017. Selected aspects of hydraulic issues in heating systems. Production Engineering Archives, 14, 27-32.

Rak, A., 2018. Selected aspects of technological innovations management in district heating companies. MATEC Web of Conferences, 183.

DOI: $10.1051 /$ matecconf/201818304003

Rezaie, B., Rosen, M.A., 2012. District heating and cooling: Review of technology and potential enhancements. Applied Energy, 93, 2-10.

DOI: 10.1016/j.apenergy.2011.04.020

Sarma U., Bazbauers G., 2016. District heating regulation: parameters for the benchmarking model. Energy Procedia, 95, 401-407.

DOI: 10.1016/j.egypro.2016.09.046.

Sipilä K., Pietiläinen J., Nuorkivi A., 2016. The building level substation - the innovation of district heating system. VTT Technical Research Centre of Finland Ltd (https://www.vtt.fi/inf/pdf/technology/2016/T250.pdf).

Tidd J., Bessant J.R, 2018. Managing Innovation: Integrating Technological, Market and Organizational Change. 6th Edition, John Wiley \& Sons Ltd, United Kingdom. 
Schneider Electric, 2012. TSB-TemperatureOptimization-eng. (https://www.schneiderelectric.com.ng/en/download/document/TSB-TemperatureOptimization-eng/).

Turski, M., Sekret, R., 2015. Konieczność reorganizacji systemów ciepłowniczych $w$ świetle zmian zachodzących w sektorze budowlano-instalacyjnym. Rynek Energii, 4, 27-34.

White, M.A., Bruton, G.D., 2011. The Management of Technology\&Innovation. A Strategic Approach. South-Western Cengage Learning, USA.

Wojdyga, K., Chorzelski, M., 2017. Chances for polish district heating systems. Energy Procedia, 116, 106-118, DOI: 10.1016/j.egypro.2017.05.059. 